\title{
Peran Mutasi Gen GRELD1 pada Defek Septum Ventrikel dan Hubungannya dengan Manifestasi Klinis
}

\author{
Sri Endah Rahayuningsih, ${ }^{1}$ Haruka Hamanoue, ${ }^{2,3}$ Naomichi Matsumoto ${ }^{2}$ \\ ${ }^{1}$ Bag Ilmu Kesehatan Anak RS Hasan Sadikin, Fakultas Kedokteran Universitas Padjadjaran Bandung \\ ${ }^{2}$ Department of Human Genetics and Obstetrics and Gynecology, University Graduate School of Medicine, \\ Yokohama, Japan.
}

\begin{abstract}
Latar belakang. Defek septum ventrikel (DSV) merupakan salah satu jenis penyakit jantung bawaan (PJB) yang paling sering ditemukan. Etiologi DSV berhubungan dengan faktor genetik, nongenetik, atau interaksi antara faktor genetik dan nongenetik. Gen CRELD1 adalah suatu gen yang terletak pada kromosom 3p25. Mutasi gen CRELD1 akan menyebabkan gangguan pada pembentukan septum interventrikular. Tujuan. Mengetahui peran mutasi gen CRELD1 pada DSV dan hubungannya dengan manifestasi klinis. Metode. Subjek penelitian adalah 61 pasien DSV dan 110 pasien kontrol tanpa PJB yang memenuhi kriteria inklusi. Deteksi mutasi gen CRELD1 dilakukan dengan pemeriksaan sekuensing terhadap isolasi DNA. Hasil. Ditemukan satu anak dengan mutasi CRELD1, mutasi yang terjadi adalah missense mutations dan tempat mutasi terletak pada ekson 10 c.1136T >C (p. Met379Thr). Mutasi tersebut tidak ditemukan pada kontrol. Mutasi gen CRELD1 terjadi pada anak dengan DSV inlet besar dan disertai hipertensi pulmonal. Ditemukan empat tempat mutasi SNPs, tiga di antaranya telah dilaporkan ke gene Bank sebagai SNPs, dan satu tempat mutasi belum pernah dilaporkan.

Kesimpulan. Didapatkan mutasi gen CRELD1 pada DSV inlet besar dan hipertensi pulmonal, sehingga perlu segera dilakukan penutupan defek ventrikel. Maka adanya mutasi gen CRELD1 dapat digunakan sebagai deteksi dini dan tata laksana yang lebih baik terhadap DSV. (Sari Pediatri 2008;10(4):225-9).
\end{abstract}

Kata kunci: defek septum ventrikel, mutasi gen, CRELD1

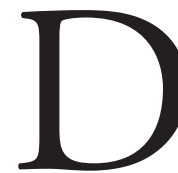

efek septum ventrikel (DSV) merupakan salah satu jenis penyakit jantung bawaan (PJB) yang paling sering ditemukan yakni sekitar 20\% dari seluruh PJB. Insidens

\section{Alamat Korespondensi:}

DR. dr. Sri Endah Rahayuningsih SpA(K). Bagian Ilmu Kesehatan Anak Fakultas Kedokteran Universitas Padjadjaran Jl. Pasteur 38 Bandung 40161. Tlp/Fax. 022-2034426 Email: endah.perkani@gmail.com
PJB adalah 8-10 di antara 1.000 kelahiran. ${ }^{1-3}$ Angka kelahiran di Indonesia 4.000.000 kelahiran/tahun, ${ }^{4}$ berarti akan terdapat penambahan jumlah kasus DSV 64.000 kasus di Indonesia, suatu jumlah yang tidak sedikit.

Sebagian besar pasien DSV kecil menutup spontan pada dua tahun pertama kehidupan. Penutupan lebih sering terjadi pada tipe muskular dibandingkan tipe perimembran. Pada DSV besar akan terjadi 
hipertensi pulmonal dan bila hal ini telah terjadi akan meningkatkan risiko operasi. Pada perkembangan selanjutnya, jika DSV tidak dioperasi akan terjadi penyakit vaskular paru yang akan meningkatkan angka kematian. ${ }^{1,2}$

Sampai saat ini mekanisme terjadinya DSV masih belum diketahui dengan pasti. Beberapa penelitian menunjukkan terdapat faktor familial atau genetik yang berperan terhadap terjadinya DSV. Faktor familial dapat disebabkan karena kelainan kromosom atau mutasi gen, ${ }^{5}$ sedangkan faktor nongenetik yang berpengaruh terhadap terjadinya DSV adalah penyakit pada ibu yaitu infeksi, kelainan metabolik, kelainan imunologik, obesitas, penggunaan obatobatan selama hamil, ras, dan usia pada saat hamil. Etiologi DSV berhubungan dengan faktor genetik, nongenetik, atau interaksi antara faktor genetik dan nongenetik. ${ }^{6-12}$

Dalam beberapa tahun terakhir ini, penelitian genetika molekular telah berkembang pesat sehingga ditemukan mutasi gen yang berperan pada mekanisme terjadinya DSV. Gen CRELD1 adalah suatu gen yang terletak pada kromosom 3p25. Gen CRELD1 akan mengekspresikan molekul-molekul adhesi yang memfasilitasi penggabungan bantalan endokardium dan matriks ekstraselular miokardium pada saat pembentukan septum interventrikular. Mutasi gen CRELD1 akan menyebabkan gangguan pada pembentukan septum interventrikular. ${ }^{13,14}$

Tujuan penelitian untuk mengetahui peran mutasi gen CRELD1 pada DSV dan hubungannya dengan manifestasi klinis.

\section{Subjek dan metode penelitian}

Subjek penelitian adalah pasien DSV dan pasien tanpa penyakit jantung bawaan sebagai kontrol yang datang ke Instalasi Rawat Jalan dan Instalasi Gawat Darurat, serta yang dirawat di Instalasi Rawat Inap Bagian Ilmu Kesehatan Anak RS dr. Hasan Sadikin Bandung. Subjek berusia $>4$ tahun dan $\leq 14$ tahun dan tidak terdapat kelainan bawaan lain selain DSV.

Pada semua pasien DSV dan pasien kontrol dilakukan anamnesis, pemeriksaan fisis, foto toraks, elektrokardiografi, dan ekokardiografi. Diagnosis ditegakkan oleh dokter Konsultan Kardiologi Anak. Pada pasien pada kelompok DSV dan kelompok kontrol yang memenuhi kriteria inklusi, diambil darah vena $5 \mathrm{ml}$, disimpan di dalam tabung EDTA dan dilakukan isolasi DNA di Unit Penelitian Kedokteran FK UNPAD Bandung. Hasil isolasi DNA dibawa ke Department of Human Genetics, Yokohama City University Graduate School of Medicine Jepang untuk dilakukan sekuensing DNA. Analisis mutasi dilakukan pada seluruh ekson dengan melalui empat tahap yaitu 1) amplifikasi dengan PCR, 2) pemurnian DNA dengan eksosap, 3) sekuensing dengan big dye terminator, dan 4) analisis mutasi sekuensing. Primer yang digunakan terdiri dari 19 primer forward dan reverse berdasarkan literatur sebelumnya. ${ }^{13}$ Penelitian dilakukan setelah mendapat persetujuan Komisi Etik. Hak cipta penelitian berada pada peneliti Indonesia.

\section{Hasil}

Selama kurun waktu penelitian Juli 2006 sampai 30 Juli 2007 di Rumah Sakit Dr Hasan Sadikin Bandung didapatkan 61 anak DSV, terdiri dari 10 DSV tipe inlet, 4 DSV tipe outlet, dan sisanya DSV tipe perimembran.

Ditemukan satu anak dengan mutasi CRELD1. Mutasi yang terjadi adalah missense mutations terletak pada ekson 10 c.1136T>C (p. Met379Thr). Mutasi tidak ditemukan pada kelompok kontrol (Gambar 1). Mutasi gen CRELD1 terjadi pada anak dengan DSV inlet besar yang disertai hipertensi pulmonal.

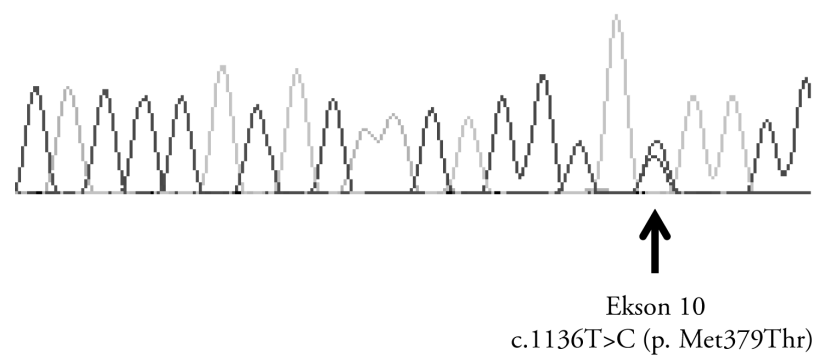

Gambar 1. Mutasi gen CRELD1 pada ekson 10 c.1136T>C (p. Met379Thr)

Ditemukan empat tempat mutasi SNPS, tiga di antaranya telah dilaporkan ke Gene Bank sebagai SNPs (rs279552, rs2302786, rs2302787), dan satu tempat mutasi yang belum dilaporkan, yang pada penelitian kami ditemukan pada 5 anak DSV dan 14 anak kelompok kontrol. (Gambar 2 dan Tabel 1) 


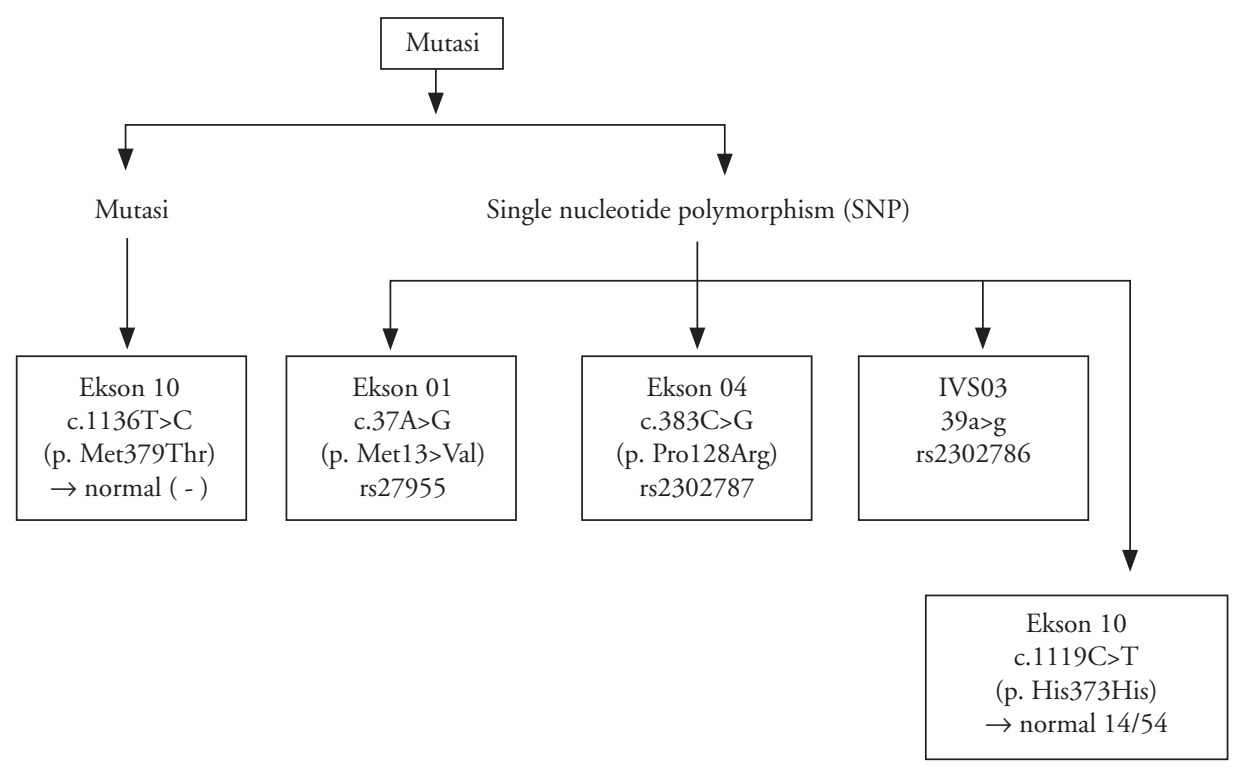

Gambar 2. Tempat lokus mutasi dan SNPs gen CRELD1

Tabel 1. Tabel mutasi/SNPs dan tempat lokus mutasi

\begin{tabular}{|c|c|c|}
\hline Mutasi/SNPs & Tempat mutasi & Ditemukan pada subjek/kontrol \\
\hline SNPs & Ex01 c.37A>G(p.Met13>Val) rs279552 & Ditemukan pada semua subjek \\
\hline SNPs & $\begin{array}{l}\text { Ex04 IVS 03>39 a>g } \\
\text { rs2302786 }\end{array}$ & $\begin{array}{l}\text { CHD005 } \\
\text { CHD } 006 \\
\text { CHD } 036 \\
\text { CHD034 }\end{array}$ \\
\hline SNPs & Ex04 c.383C>G(p. Pro128Arg) rs2302787 & $\begin{array}{l}\text { CHD003 } \\
\text { CHD } 005 \\
\text { CHD } 036 \\
\text { CHD } 058 \\
\text { CHD } 061\end{array}$ \\
\hline SNPs & Ex10 c.1119C>T(p. His373His) & $\begin{array}{l}\text { CHD } 005 \\
\text { CHD } 006 \\
\text { CHD } 091 \\
\text { CHD } 034 \\
\text { Ditemukan pada } 14 \text { kontrol }\end{array}$ \\
\hline Mutasi & Ex10 c. $1136 \mathrm{~T}>\mathrm{C}(\mathrm{p}$. Met379Thr $)$ & CHD034 \\
\hline
\end{tabular}

\section{Pembahasan}

Terjadinya defek septum ventrikel (DSV) sebagai akibat gangguan pada masa embriogenesis yaitu saat pembentukan septum intraventrikel. Sampai saat ini belum diketahui jalur molekular yang menerangkan morfogenesis septum ventrikel dan tidak ada satu jalur molekular yang spesifik memodulasi septum ventrikel pars membranasea, muskular, inlet, outlet, atau jaringan lain. Penelitian sebelumnya menunjukkan terdapat interaksi antara molekul-molekul yang berbeda dan interaksi antara jalur-jalur molekular yang berperan pada morfogenesis septum ventrikel, sehingga pembentukan septum interventrikel 
dipengaruhi oleh multifaktor. ${ }^{15,16}$ Beberapa peneliti mencoba untuk menerangkan mekanisme mutasi gen terhadap kejadian DSV, di antaranya penelitian yang dilakukan Robinson $\mathrm{dkk}^{13}$ yang menemukan 6\% dari 52 anak dengan defek septum atrioventrikular (DSAV) mengalami missense mutation gen CRELD1, mutasi tersebut tidak ditemukan pada kontrol normal.

Pada proses pembentukan septum interventrikel, bantalan endokardium akan meluas dan bergabung dengan matriks ekstraselular yang berasal dari miokardium untuk membentuk septum interventrikel pars inlet. Penggabungan tersebut memerlukan peran protein yang terdiri dari molekul sel adhesi. CRELD1 adalah gen yang berperan pada sintesis protein yang termasuk dalam kelompok molekul sel adesi, sehingga mutasi gen CRELD1 diduga akan mengganggu proses penggabungan tersebut. ${ }^{13,14}$

Mutasi adalah perubahan permanen pada urutan nuklelotida. Mutasi tidak selalu menyebabkan manifestasi klinis. Mutasi dapat menyebabkan perubahan pada fungsi maupun struktur protein tertentu atau keduanya. Adanya mutasi akan menyebabkan perubahan struktur protein dan dengan demikian akan mempengaruhi fungsi. ${ }^{15}$ Tidak semua mutasi mempunyai konsekuensi klinik atau mutasi dapat mempunyai manifestasi klinik yang tidak berarti. Terdapat banyak protein yang mempunyai variasi lebih dari satu di dalam populasi tanpa menimbulkan penyakit. Hal tersebut dikenal sebagai single nucleotide polymorphism (SNP), karena setiap orang mempunyai materi genetik yang terdiri dari SNP yang unik yang berbeda dengan orang lain, dan SNP adalah variasi genetik pada urutan DNA dan terjadi lebih dari $1 \%$ populasi. Untuk memenuhi definisi $>1 \%$, pada penelitian kami pada kelompok kontrol harus ditemukan $>1$ anak dengan urutan DNA yang sama dengan kelompok DSV. Dikatakan SNP jika urutan DNA tersebut didapatkan pada DSV walaupun tidak didapatkan pada kontrol, namun urutan DNA tersebut telah dilaporkan ke Gene Bank (Gambar 3) Beberapa SNP sudah dilaporkan ke Gene Bank. ${ }^{17}$ Penelitian kami menemukan tiga tempat SNPs yang sudah dilaporkan dan satu tempat SNPs yang belum pernah dilaporkan di Gene Bank. single nucleotide polymorphism (SNP) merupakan perubahan nukelotida yang terjadi pada kontrol maupun pada DSV, suatu usaha dari mahluk hidup untuk bertahan hidup akibat perubahan lingkungan. ${ }^{17}$
Secara anatomis DSV dapat diklasifikasikan sesuai letak defeknya. Forum Ilmiah Kardiologi Anak Indonesia membuat klasifikasi DSV berdasarkan klasifikasi oleh Soto $\mathrm{dkk}^{18}$ yaitu (1) DSV perimembran outlet, inlet, trabekular, konfluens; (2) DSV muskular posterior, trabekular, infundibular dan (3) DSV subarterial (doubly commited subarterial). Penelitian kami menunjukkan mutasi CRELD1 terjadi pada DSV tipe inlet yang secara embriologi septum interventrikel berasal dari bantalan endokardium. ${ }^{13,14}$

Manifestasi klinis DSV kecil pada umumnya asimtomatik, tetapi pada DSV besar terjadi pirau dari ventrikel kiri menunju ventrikel kanan yang menyebabkan peningkatan aliran darah ke paru sehingga terjadilah hipertensi pulmonal. Pada awalnya hipertensi pulmonal terjadi akibat aliran darah yang meningkat ke paru. Jika keadaan ini berlanjut, akan terjadi kerusakan dinding pembuluh darah paru yang diganti oleh jaringan ikat, akibatnya hipertensi pulmonal terjadi karena peningkatan tekanan. ${ }^{1,2}$ Kami menemukan mutasi gen CRELD1 pada anak dengan DSV inlet besar dan hipertensi pulmonal, sehingga perlu segera dilakukan penutupan defek ventrikel.

Penelitian menunjukkan mutasi gen CRELD1 pada DSV dan mutasi tidak ditemukan pada pasien kontrol, ini merupakan laporan pertama mutasi gen CRELD1 di Indonesia. Mutasi yang terjadi adalah missense mutations yaitu satu asam amino diganti oleh asam amino lain pada gen target. ${ }^{17}$

\section{Kesimpulan}

Penelitian menunjukkan adanya mutasi gen CRELD1 pada anak dengan DSV inlet besar dan hipertensi pulmonal yang memerlukan tindakan penutupan defek. Maka adanya mutasi gen tersebut dapat digunakan sebagai deteksi dini dan tata laksana yang lebih baik terhadap DSV.

\section{Ucapan terimakasih}

Penelitian ini mendapat dana dari Research Grant from the Ministry of Health, Labour and Welfare (N. M.) and Grant-in-aid for scientific research on priority areas from the ministry of education, culture, sports, science and technology of Japan (N. M.) 


\section{Daftar Pustaka}

1. Park MK. Pediatric cardiology for practitioners. Edisi ke-5. Philadelphia: Mosby; 2008.h.166-74.

2. McDaniel NL, Gutgesell HP. Ventricular septal defects. Dalam: Allen HD, Gutgesell HP, Clark EB, Driscoll DJ, penyunting. Moss and Adam's Heart disease in infants, children, and adolescents. Edisi ke-6. Philadelphia; William \& Wilkins; 2001.h.636-51.

3. Hoffman JIE, Kaplan S. The incidence of congenital heart disease. J Am Coll Cardiol 2002;39:1890-900.

4. Dinas Kesehatan Provinsi Jawa Barat. Profil kesehatan provinsi Jawa Barat. Bandung: Departemen Kesehatan Provinsi Jawa Barat; 2004.

5. Nora JJ, Nora AH. Recurrence risks in children having one parent with a congenital heart disease. Circulations 1976;53:701-2.

6. Botto LD, Cornea A, Erickson JD. Racial and temporal variations in the prevalence of heart disease. Pediatrics 2001;107:32-42.

7. Forrester MB, Merz RD. Descriptive epidemiology of selected congenital heart defects, Hawaii,1986-1999. Paed Perinatol Epid 2004;18:415-24.

8. Morales-Suarez-Varela MM, Bille C, Christensen K, Olsen J. Smoking habits, nicotine use, and congenital malformations. Obstet \& Gynecol 2006;107:51-7.

9. Clark EB. Etiology of congenital cardiovascular malformations: epidemiology and genetics. Dalam: Allen HD, Gutgesell HP, Clark EB, Driscoll DJ, penyunting. Moss and Adam's heart disease in infants, children, and adolescents. Edisi ke-6. Philadelphia: William \&
Wilkins; 2001.h.64-79.

10. Mone SM, Gillman MW, Miller TL, Herman EH, Lipshultz SE. Effects of environmental exposures on the cardiovascular system: prenatal period through adolescence. Pediatrics 2004;113:1058-69.

11. Brent RL. Addressing environmentally caused human birth defects. Ped Rev 2001;22:153-65.

12. Cedergren MI, Kallen BAJ. Maternal obesity and infant heart defects. Obes Res 2003;11:123-8

13. Robinson SW. Morris CD, Goldmuntz E. Missense mutations in CRELD1 are associated with cardiac atrioventricular septal defects. Am J Hum Genet 2003;72:1047-52.

14. Rupp PA, Fouad GT. Egelston CA. Identification, genomic organization and mRNA expression of CRLED? the founding member of a unique family o matricellular proteins. Gene 2002;293:47-57.

15. Gittenberger-de Groot AC, Bartelings MM, Deruiter MC, Poelmann RE. Basics of cardiac development for the understanding of congenital heart malformations. Ped Res 2005;57:169-76.

16. Lamers WH, Moorman AFM. Cardiac septation: a late contribution of the embryonic primary myocardium to the heart morphogenesis. Circ Res 2002;91:93-103.

17. Strachan T, Read AP. Human molecular genetics. Edisi ke-3. New York: Garland Science; 2004.h.463-5.

18. Putra ST. Pendekatan diagnosis penyakit jantung bawaan sianotik. Dalam: Putra ST, Advani N, Rahajoe AU, penyunting. Dasar-dasar Diagnosis \& Tatalaksana Penyakit Jantung pada Anak. Forum Ilmiah Kardiologi Anak 1996:131-54. 